\title{
Microdeletion syndromes and psychiatry: an update
}

\author{
Melvyn W. B. Zhang, Nikki Fong, Ying Hui Quek, Cyrus S. H. Ho, Beng Yeong Ng \\ \& Roger C. M. Ho
}

\begin{abstract}
SUMMARY
Microdeletion syndrome is an important topic in intellectual disability, associated with various psychiatric symptoms, such as autism, attention deficit, hyperactivity, obsession and compulsion, and psychosis. In this article, we provide a clinical update on the following syndromes and their associated psychiatric disorders: PraderWilli syndrome, Angelman syndrome, Williams syndrome, Wolf-Hirschhorn syndrome, cri du chat syndrome, DiGeorge syndrome and RubinsteinTaybi syndrome.
\end{abstract}

\section{LEARNING OBJECTIVES}

- Gain an up-to-date understanding of the microdeletion syndromes commonly seen in daily practice

- Appreciate the association between underlying chromosomal abnormalities and the resultant intellectual disabilities in microdeletion syndromes

- Gain up-to-date knowledge about the treatment options for the various microdeletion syndromes commonly seen in daily practice

\section{DECLARATION OF INTEREST}

None

Microdeletion syndromes have been found to be associated with various psychiatric comorbidities, such as hyperkinetic disorder, autism spectrum disorders, obsessive-compulsive disorders for individuals diagnosed with Prader-Willi syndrome (PWS) (Dykens 1992), or schizophrenia and schizoaffective disorders for individuals with 22q11.2 deletion syndrome (22q11DS) (Gothelf 2009). The prevalence of intellectual disabilities has been estimated to be approximately 1-3\% in high- and middle-income countries. This may result in marked psychosocial impairments, particularly for those with moderate, severe and profound intellectual disabilities. Microdeletion is considered to be one of the prenatal causes of intellectual disability. Other prenatal causes include central nervous system infections, exposure to radiation, maternal use of various substances and drugs, as well as malnutrition.
Microdeletions are alterations of the chromosomes that cannot be detected by conventional light microscopy or other conventional methodologies, and are usually approximately $1-3 \mathrm{Mb}$ long. Although the site and size of the deletion may vary for a particular syndrome, it should be noted that a particular area of a critical gene is usually involved. Given that critical areas of gene are affected, the deletion often results in characteristic phenotypic changes due to the lack of expression of particular segments of genes. To date, the visualisation of these deletions has only been possible via methods such as comparative genomic hybridisation or fluorescence in situ hybridisation (FISH). Such consistent alterations in DNA content have been associated with some well-established malformation syndromes (Schinzel 1988). In circumstances in which psychiatrists suspect the presence of an underlying genetic disorder, it is thus recommended for the individual to undergo genetic testing. Visualisation of the deletions would be done using the methodologies described above.

The most common microdeletion syndromes are listed in Box 1, together with the other known microdeletion syndromes. Table 1 gives an overview of the common syndromes. The latest microdeletion syndrome to be discovered is the 8p23.1 syndrome, which involves the duplication of a region of chromosome 8 . The phenotypic changes include changes in speech, developmental delays as well as cardiovascular-related disorders.

It is hoped that this review article will provide the psychiatrist with an update about the clinical features of each of the common microdeletion syndromes and their association with intellectual disabilities, and share recent insights and updates regarding clinical management and genetic testing for each of the individual syndromes.

\section{Chromosome 22q11.2 deletion syndrome}

\section{Background}

This syndrome (22q11DS) refers to patients with a hemizygous deletion of chromosome 22q11.2. The syndrome is well recognised worldwide and commonly known as either DiGeorge syndrome
Melvyn Zhang is an associate consultant at the National Addictions Management Service at the Institute of Mental Health in Singapore. He is also an adjunct research scientist with the Biomedical Institute for Global Health Research \& Technology (BIGHEART). He has multiple publications in high impact factor psychiatry journals, and he has a special interest in the application of information technologies in psychiatry. Nikki Fong is currently a medical officer/trainee with the Ministry of Health Holdings, Singapore. Ying Hui Quek is a final-year medical undergraduate student at the Yong Loo Lin School of Medicine, National University of Singapore. Cyrus $\mathbf{H o}$ is an associate consultant at the National University Hospital, Singapore. He has special interests in neuropsychiatry, neurorehabilitation and the interface between medicine and psychiatry. Beng Yeong $\mathbf{N g}$ is a psychiatrist at the Singapore General Hospital. Roger Ho is an associate professor and consultant psychiatrist at the National University Hospital, Singapore. He has a special interest in psychoneuroimmunology and the interface between medicine and psychiatry.

Correspondence Dr Melvyn Zhang, Associate Consultant and Adjunct Research Scientist, MD6, 14 Medical Drive, \#14-01, Singapore 117599. Email: melvyn_wb_zhang@ imh.com.sg

Copyright and usage (C) The Royal College of Psychiatrists 2017. 
BOX 1 Microdeletion syndromes

\begin{tabular}{|c|c|}
\hline $\begin{array}{l}\text { Most common microdeletion syndromes } \\
15 q 11-13 \text { maternal deletion syndrome } \\
\text { (Angelman syndrome) }\end{array}$ & $\begin{array}{l}\text { 8q24.11 deletion syndrome (Langer- } \\
\text { Giedion syndrome or trichorhinophalangeal } \\
\text { syndrome type II) }\end{array}$ \\
\hline \multirow{2}{*}{$\begin{array}{l}15 q 11-13 \text { paternal deletion syndrome } \\
\text { (Prader-Willi syndrome) }\end{array}$} & 9q22 deletion syndrome \\
\hline & 9q34.3 deletion syndrome \\
\hline $\begin{array}{l}\text { 7q11.23 deletion syndrome (Williams } \\
\text { syndrome) }\end{array}$ & $\begin{array}{l}\text { DiGeorge syndrome/velocardiofacial } \\
\text { syndrome complex } 2\end{array}$ \\
\hline \multirow{2}{*}{$\begin{array}{l}\text { 4p deletion syndrome (Wolf-Hirschhorn } \\
\text { syndrome) }\end{array}$} & $11 q 13$ deletion syndrome (WAGR syndrome) \\
\hline & 11q11.2 deletion syndrome (Potocki-Shaffer \\
\hline Cri du chat syndrome & syndrome) \\
\hline DiGeorge syndrome & 11q24.1 (Jacobsen syndrome) \\
\hline Rubinstein-Taybi syndrome & 13q14 deletion syndrome (retinoblastoma \\
\hline Other microdeletion syndromes & \\
\hline 1q36 deletion syndrome & 15q11.2 deletion syndrome (BP1-2) \\
\hline 1q21.1 deletion syndrome & $15 q 13.3$ deletion syndrome \\
\hline Thrombocytopenia-absent radius syndrome & $15 q 15.3$ deletion syndrome \\
\hline 2q15-16.1 deletion syndrome & $15 q 24$ deletion syndrome \\
\hline 2q23.1 deletion syndrome & 16p13.11 deletion syndrome \\
\hline 2q37 deletion syndrome & 17p13.3 deletion syndrome \\
\hline $3 p$ deletion syndrome & 17p1.2 deletion syndrome \\
\hline 3q29 deletion syndrome & $17 q 12$ deletion syndrome \\
\hline $5 q 35$ deletion syndrome (Sotos syndrome) & 17q21.31 deletion syndrome \\
\hline 6p25 deletion syndrome & 18p deletion syndrome \\
\hline 8p23.1 deletion syndrome & 20p11 deletion syndrome \\
\hline $\begin{array}{l}\text { 8q22.1 deletion syndrome (Nablus mask-li } \\
\text { facial syndrome) }\end{array}$ & \\
\hline
\end{tabular}

or velocardiofacial syndrome. The hemizygous deletion is inherited in an autosomal dominant pattern. Hence, affected parents have a substantial risk of passing on the deletion to their children; 22q11DS is estimated to occur in nearly 1 in 3000 children.

\section{Clinical features}

The clinical features of 22q11DS are diverse, but common features include a conotruncal cardiac anomaly, mild-to-moderate immune deficiency, developmental delays, palatal dysfunction, and feeding difficulties in infants (Shprintzen 2008). Of note, patients with 22q11DS do not tend to have noticeable facial dysmorphisms (Shprintzen 2008). More importantly, 22q11DS is commonly associated with congenital heart disease; the deletion is found in a large percentage of children with conotruncal heart anomalies (Goldmuntz 1998). Palatal dysfunction is also relatively common, with $8 \%$ of children with cleft palates, submucous cleft palate and occult submucous cleft palates having 22q11DS (Shprintzen 1985). Despite the fact that immune disorders are also relatively common, few affected individuals have severe immunodeficiency (Shprintzen 2008).

\section{Psychiatric comorbidity and intellectual disabilities}

Speech and language impairment is commonly seen, with approximately $75 \%$ of affected individuals having hypernasal speech and a high percentage having severe articulation impairment (Shprintzen 2008). Speech development is usually mildly delayed and receptive language abilities exceed expressive abilities (Golding-Kushner 1985).

Psychiatric disorders seen in children and adolescents with 22q11DS include attentiondeficit hyperactivity disorder (ADHD; 35-46\%) (Niarchou 2015), oppositional defiant disorder (16-43\%), specific and social phobias (23-61\%), generalised anxiety disorder (GAD; 17-29\%), separation anxiety disorder (16-21\%), obsessivecompulsive disorder (OCD; 4-33\%), major depressive disorder and dysthymia (10-20\%) and autism spectrum disorders (14-45\%) (Tang 2015). By late adolescence and adulthood, up to one-third of patients with 22q11DS develop psychotic disorders resembling schizophrenia and schizoaffective disorders (Gothelf 2009). Individuals diagnosed with schizophrenia in the general population tend to have a premorbid period in which they have gradual worsening of their social and academic functioning. Individuals with 22q11DS tend to have a more chronic and prolonged duration of impaired functioning, from childhood to adolescence (Radoeva 2017).

The average full-scale IQ score in affected individuals is in the mid-70s, within the borderline intelligence range (Swillen 1997); 25 to 40\% score in the intellectual disability range. The cognitive profile of individuals with this condition is characterised by relative strengths in the areas of reading, spelling, and rote memory, and relative weaknesses in the areas of visuospatial memory and arithmetic (Simon 2005).

\section{Prognosis}

With improved palliative cardiac repair and medical management of immunodeficiency, infant mortality in 22q11DS is approximately 8\% (Ryan 1997). Individuals with 22q11DS can have normal lifespans if they undergo corrective cardiac procedures. The immune problems for some of these individuals also tend to remit over time. The associated endocrinology problems can be treated with appropriate medications (Shprintzen 2008). 
TABLE 1 Summary of the core features of each of the common microdeletion syndromes

\begin{tabular}{|c|c|c|c|c|c|c|c|}
\hline & $\begin{array}{l}\text { Prader-Willi } \\
\text { syndrome }\end{array}$ & $\begin{array}{l}\text { Angelman } \\
\text { syndrome }\end{array}$ & $\begin{array}{l}\text { Williams } \\
\text { syndrome }\end{array}$ & $\begin{array}{l}\text { Wolf- } \\
\text { Hirschhorn } \\
\text { syndrome }\end{array}$ & $\begin{array}{l}\text { Cri du chat } \\
\text { syndrome }\end{array}$ & $\begin{array}{l}\text { DiGeorge } \\
\text { syndrome }\end{array}$ & $\begin{array}{l}\text { Rubinstein- } \\
\text { Taybi } \\
\text { syndrome }\end{array}$ \\
\hline Prevalence & 1 in 50000 & $\begin{array}{l}1 \text { in } 10000 \text { to } \\
1 \text { in } 20000\end{array}$ & $\begin{array}{l}1 \text { in } 7500 \text { to } \\
1 \text { in } 20000\end{array}$ & $\begin{array}{l}1 \text { in } 50000 \text { to } \\
1 \text { in } 20000\end{array}$ & $\begin{array}{l}1 \text { in } 15000 \text { to } \\
1 \text { in } 50000\end{array}$ & 1 in 3000 & $\begin{array}{l}1 \text { in } 100000 \text { to } \\
1 \text { in } 125000\end{array}$ \\
\hline $\begin{array}{l}\text { Clinical } \\
\text { features }\end{array}$ & $\begin{array}{l}\text { Low birth } \\
\text { weight, } \\
\text { hypotonia, } \\
\text { feeding } \\
\text { difficulties, } \\
\text { hyperphagia, } \\
\text { obesity }\end{array}$ & $\begin{array}{l}\text { Ataxic, } \\
\text { tremulous } \\
\text { movement of } \\
\text { limbs, frequently } \\
\text { smiling with } \\
\text { associated } \\
\text { developmental } \\
\text { delays }\end{array}$ & $\begin{array}{l}\text { Elfin-like facies, } \\
\text { broad brow, flat } \\
\text { nasal bridge, } \\
\text { short upturned } \\
\text { nose, irregular } \\
\text { dentition, } \\
\text { 'cocktail party' } \\
\text { personality }\end{array}$ & $\begin{array}{l}\text { Characteristic } \\
\text { facial features } \\
\text { such as prominent } \\
\text { nose, prominence } \\
\text { of glabella, } \\
\text { hypertelorism, } \\
\text { epicanthal fold } \\
\text { and distinct } \\
\text { downturned } \\
\text { corners of the } \\
\text { mouth }\end{array}$ & $\begin{array}{l}\text { Low birth } \\
\text { weight, } \\
\text { dysmorphic } \\
\text { facies, } \\
\text { prominent large } \\
\text { nasal bridge, } \\
\text { hypertelorism, } \\
\text { cat-like cry }\end{array}$ & $\begin{array}{l}\text { Conotruncal } \\
\text { cardiac anomaly, } \\
\text { mild/moderate } \\
\text { immune } \\
\text { deficiency, } \\
\text { developmental } \\
\text { delay, typical } \\
\text { facies, palatal } \\
\text { dysfunction, } \\
\text { feeding } \\
\text { difficulties in } \\
\text { infants }\end{array}$ & $\begin{array}{l}\text { Intellectual } \\
\text { disability, } \\
\text { postnatal } \\
\text { growth } \\
\text { deficiency, } \\
\text { microcephaly, } \\
\text { specific facial } \\
\text { characteristics, } \\
\text { broad thumbs } \\
\text { and big toes }\end{array}$ \\
\hline 10 & $\begin{array}{l}\text { Mild disability } \\
\text { (mean I0 60-70) }\end{array}$ & $\begin{array}{l}\text { Severe to } \\
\text { profound } \\
\text { intellectual } \\
\text { disability }\end{array}$ & $\begin{array}{l}\text { Average } 10 \\
50-60, \text { better } \\
\text { verbal than } \\
\text { motor abilities }\end{array}$ & $\begin{array}{l}\text { Mild intellectual } \\
\text { disability in } \\
10 \% \text { of cases, } \\
\text { moderate in } \\
25 \% \text { and severe/ } \\
\text { profound in } 65 \%\end{array}$ & $\begin{array}{l}\text { Severe mental } \\
\text { and development } \\
\text { retardation, } 10 \\
\text { usually between } \\
\text { 20th and 50th } \\
\text { per centile }\end{array}$ & $\begin{array}{l}\text { Average full- } \\
\text { scale } 10 \text { in the } \\
\text { mid-70s }\end{array}$ & $\begin{array}{l}\text { Global } \\
\text { intellectual } \\
\text { disability is } \\
\text { characteristic, } \\
\text { with an average } \\
10 \text { of } 35-50\end{array}$ \\
\hline Comorbidities & $\begin{array}{l}\text { Sleep, } \\
\text { behavioural, } \\
\text { psychiatric } \\
\text { and endocrine } \\
\text { abnormalities }\end{array}$ & $\begin{array}{l}\text { Orthopaedic } \\
\text { and movement } \\
\text { difficulties, } \\
\text { behavioural and } \\
\text { sleep problems, } \\
\text { epileptic } \\
\text { seizures, } \\
\text { gastrointestinal } \\
\text { problems }\end{array}$ & $\begin{array}{l}\text { Growth-related, } \\
\text { cardiovascular, } \\
\text { endocrine, } \\
\text { neurological and } \\
\text { genitourinary } \\
\text { problems }\end{array}$ & $\begin{array}{l}\text { Musculoskeletal, } \\
\text { neurological and } \\
\text { midline defects }\end{array}$ & $\begin{array}{l}\text { Growth } \\
\text { retardation, } \\
\text { sensory issues } \\
\text { and cardiac } \\
\text { deformities }\end{array}$ & $\begin{array}{l}\text { Heart } \\
\text { abnormalities, } \\
\text { palatal } \\
\text { dysfunction, } \\
\text { immune } \\
\text { disorders, } \\
\text { comorbid } \\
\text { psychiatric } \\
\text { disorders }\end{array}$ & $\begin{array}{l}\text { Growth/weight } \\
\text { problems, } \\
\text { constipation, } \\
\text { hypotonia, } \\
\text { congenital heart } \\
\text { defects, renal } \\
\text { anomalies, } \\
\text { ophthalmologic } \\
\text { problems, } \\
\text { orthopaedic } \\
\text { problems }\end{array}$ \\
\hline Treatment & $\begin{array}{l}\text { Manage poor } \\
\text { feeding, evaluate } \\
\text { for endocrine } \\
\text { abnormalities, } \\
\text { manage obesity, } \\
\text { monitoring for } \\
\text { scoliosis and } \\
\text { therapy for } \\
\text { behavioural } \\
\text { issues }\end{array}$ & $\begin{array}{l}\text { Evaluate } \\
\text { and treat for } \\
\text { neurological } \\
\text { complications; } \\
\text { evaluate } \\
\text { for feeding } \\
\text { difficulties; } \\
\text { specialised } \\
\text { therapy for } \\
\text { developmental } \\
\text { delays }\end{array}$ & $\begin{array}{l}\text { Routine } \\
\text { assessment } \\
\text { with accurate } \\
\text { assessment } \\
\text { of growth, } \\
\text { blood pressure } \\
\text { monitoring, } \\
\text { developmental } \\
\text { assessment, } \\
\text { routine vision/ } \\
\text { hearing } \\
\text { screening } \\
\text { and cardiac } \\
\text { evaluation }\end{array}$ & $\begin{array}{l}\text { Largely symptom- } \\
\text { targeted and } \\
\text { supportive at best }\end{array}$ & $\begin{array}{l}\text { No specific } \\
\text { management } \\
\text { approach } \\
\text { has been } \\
\text { recommended }\end{array}$ & $\begin{array}{l}\text { No specific } \\
\text { management } \\
\text { approach } \\
\text { has been } \\
\text { recommended }\end{array}$ & $\begin{array}{l}\text { No specific } \\
\text { management } \\
\text { approach } \\
\text { has been } \\
\text { recommended }\end{array}$ \\
\hline Prognosis & $\begin{array}{l}\text { Able to reach } \\
\text { adulthood and } \\
\text { function in group } \\
\text { home settings }\end{array}$ & $\begin{array}{l}\text { No data on } \\
\text { estimated life } \\
\text { expectancy }\end{array}$ & $\begin{array}{l}\text { Generally low } \\
\text { educational and } \\
\text { employment } \\
\text { attainments }\end{array}$ & $\begin{array}{l}\text { Favourable only } \\
\text { if the three major } \\
\text { medical problems } \\
\text { are looked into }\end{array}$ & $\begin{array}{l}\text { Mortality is } \\
\text { about } 10 \% ; 75 \% \\
\text { of deaths in the } \\
\text { first months of } \\
\text { life, up to } 90 \% \text { in } \\
\text { the first year }\end{array}$ & $\begin{array}{l}\text { Low infant } \\
\text { mortality; life } \\
\text { spans tend to } \\
\text { be normal if } \\
\text { problems are } \\
\text { dealt with }\end{array}$ & $\begin{array}{l}\text { Normal life } \\
\text { expectancy }\end{array}$ \\
\hline
\end{tabular}

\section{Prader-Willi syndrome}

\section{Background}

PWS is a complex multisystem genetic disorder that is caused by the lack of expression of paternally inherited imprinted genes on chromosome 15q11-q13 (Jin 2011). The main gene implicated is $S N R P N$ (small nuclear ribonucleoprotein N). This encodes a protein involved in pre-mRNA splicing and processing in brain and muscle (Young 2005). Approximately $70 \%$ of cases result from $4-\mathrm{Mb}$ microdeletions involving the paternally derived chromosome 15. Approximately $25 \%$ of cases result from maternal uniparental disomy (UPD) for chromosome 15. The remaining cases are due to a mutation or tiny deletion in the PWS imprinting centre or $S N R P N$ promotor. The prevalence of PWS varies from 1 in 8000 to 1 in 20000 , with 
population prevalence at approximately 1 in 50000 (Jin 2011).

\section{Clinical features}

The common clinical features of PWS include low birth weight, severe hypotonia and feeding difficulties in early infancy, followed by hyperphagia and obesity starting in early childhood (Buiting 2010). Common comorbidities include sleep abnormalities, behavioural and psychiatric disturbances, and endocrinological abnormalities. Individuals with PWS are predisposed to sleep-disordered breathing, including central and obstructive sleep apnoea, abnormal arousal, abnormal circadian rhythms in rapid eye movement (REM) sleep, reduced REM latency, and abnormal response to hypercapnia, as well as excessive daytime sleepiness (Nixon 2002). PWS has been found to be associated with endocrinological abnormalities such as obesity, growth hormone deficiency and hypogonadism.

\section{Psychiatric comorbidity and intellectual disabilities}

Previous research has found that children with PWS tend to have behavioural and psychiatric disturbances, which usually include behavioural patterns such as temper tantrums, obsessivecompulsive characteristics, autism spectrum disorder, and attention-deficit hyperactivity symptoms (Dykens 1992). Previous research has found a close association between this microdeletion syndrome and bipolar disorder (Boer 2002; Verhoeven 2003). Based on a prior population-based study of 25 individuals aged 18 or more, it was ascertained that $28 \%$ have an underlying bipolar disorder and the medium age of onset is approximately 26 years (Boer 2002). A combination of medications such as antipsychotics and mood stabilisers have been used in the treatment of those diagnosed with bipolar disorder (Boer 2002).

In addition, previous research has highlighted that most individuals with PWS are diagnosed with mild intellectual disability, with a mean IQ of $60-70$. However, $20 \%$ of individuals with PWS are diagnosed as having moderate intellectual disability (Jin 2011).

\section{Clinical management}

Care for patients with PWS includes management of hypotonia or poor feeding, evaluation for endocrine abnormalities, management of obesity, monitoring for scoliosis and therapy for behavioural issues. With regards to the management of the hyperphagia and binge eating behaviours, pharmacological approaches such as use of anorectic agents have not shown any effectiveness (Martin 1998). Psychiatric medications such as selective serotonin reuptake inhibitors might regulate the behavioural symptoms commonly seen in patients with PWS, but these do not mediate the binge eating and weight gain symptoms (Martin 1998). Psychotropic drugs could be initiated to help with behavioural management (Martin 1998).

\section{Prognosis}

Patients with PWS frequently reach adulthood and are able to function in a group home setting, performing vocational work or attending community college classes. Complications from hypogonadism (e.g. osteoporosis/pathological fracture), behavioural issues (e.g. temper tantrums and stubbornness) and morbid obesity (e.g. type 2 diabetes mellitus and cor pulmonale) may shorten life expectancy and affect the quality of life (Jin 2011).

\section{Angelman syndrome}

\section{Background}

Angelman syndrome involves microdeletion of the maternally derived chromosome 15 in approximately $70 \%$ of cases, and paternal UPD for chromosome 15 in $2-3 \%$ of cases. Most commonly, the microdeletion involves the 15q12 site. Most of the remainder of cases are caused by mutations in $U B E 3 A$ (ubiquitin-protein ligase E3A) or another gene involved in the imprinting process. Severe psychomotor retardation is attributed to abnormal expression of $U B E 3 A$, which encodes a protein ligase thought to play an important part in the localisation of proteins in the brain (Young 2005). The incidence of Angelman syndrome is estimated to be between 1 in 10000 and 1 in 20000 (Williams 2005).

\section{Clinical features}

Patients with Angelman syndrome tend to have ataxia and tremulous limb movements. They tend to have a happy demeanour with sudden bursts of laughter. In addition, they often have developmental delays (Williams 2006). Some of the common physical features of the syndrome include hypotonia, microbrachycephaly, vertical inclination of skull base, occipital furrow, fair hair, ocular abnormalities, midface hypoplasia, macrostomia and widely spaced teeth, tongue protrusion with drooling, and prognathism (Schinzel 1988). The most common comorbidities include orthopaedic and movement difficulties, behavioural issues and sleep problems, epileptic seizures and gastrointestinal problems (Larson 2015). 


\section{Psychiatric comorbidity and intellectual disabilities}

Individuals with Angelman syndrome tend to have severe to profound intellectual disabilities, with developmental delays that are first noted at around 6 months of age. They tend to be able to sit unsupported at only 12 months of age, crawl at the age of 18-24 months and walk at the age of 4 years (Clayton-Smith 1993). They tend to have limited vocabulary of only one or two words, despite having reasonable comprehension of simple commands and sentences (Laan 1999). It should be noted that the results of any neuropsychological tests might be confounded by the patient's inability to focus, underlying hyperactivity and inability to communicate (Williams 2010).

Prior research has highlighted that another common comorbid condition in Angelman syndrome (in addition to intellectual disability) is autism spectrum disorder (Ornoy 2016). Individuals with class I deletions, which involve multiple breakpoints in chromosome 15q11-13, were found to have a higher incidence of autism spectrum disorder.

\section{Clinical management}

Eighty per cent of patients with Angelman syndrome have neurological complications such as epilepsy. Early screening is therefore essential, as are further evaluations such as electroencephalogram (EEG) to check for the presence of seizures. In addition, in view of the developmental delays as well as the communication difficulties, patients should be referred for speech therapy. For patients with gait and movement problems, physical and occupational therapy should be considered. With regards to sleep disturbances, medications such as melatonin could be considered.

\section{Prognosis}

There are no data on the life expectancy for patients with Angelman syndrome. It is to be expected that patients with Angelman syndrome would continue to have epileptic seizures throughout adulthood, with atypical absence seizures and myoclonic seizures being the most prominent. With advancing age, adults tend to become less active, largely due to joint contractures, thus leading to significant difficulties with walking. Some individuals eventually require a wheelchair (Buggenhout 2009).

\section{Williams syndrome}

\section{Background}

Williams syndrome is caused by a $\sim 1.5-\mathrm{Mb}$ deletion encompassing the elastin gene (ELN) at 7q11.23 (Morris 2000). The deletion results in the loss of approximately 28 genes, including ELN itself. The estimated prevalence of Williams syndrome ranges from 1 in 7500 to 1 in 20000 (Martens 2008).

\section{Clinical features}

Individuals with Williams syndrome have a characteristic elfin facies, with a broad brow, flat nasal bridge, short upturned nose, wide mouth with full lips, and irregular dentition (Morris 1999). They often have an engaging 'cocktail party' personality which conceals mild intellectual disability (Young 2005). The most common comorbidities include growth-related problems, and cardiovascular, endocrine, neurological and genitourinary abnormalities.

\section{Psychiatric comorbidity and intellectual disabilities}

Individuals with Williams syndrome are noted to have mild-to-moderate developmental delay. In neuropsychological testing, it is consistently noted that they tend to have higher verbal intelligence scores compared with their performance intelligence scores. The average IQ for patients with Williams syndrome lies between 50 and 60 (Martens 2008). Hence, it is not uncommon to find that these individuals have better verbal abilities as compared to motor abilities (Martens 2008). Recent studies have found increased prevalence of autism spectrum disorders among patients with Williams syndrome (Ornoy 2016). Clinicians need to be cognisant of the fact that the microdeletion in Williams syndrome could lead to a range of social communications deficits, ranging from lack of verbal language to being excessively talkative (Tordjman 2012).

\section{Clinical management}

It is recommended that a multidisciplinary team follows up the patient, owing to the numerous complications associated with Williams syndrome. The American Academy of Pediatrics guidance (Committee on Genetics 2001) previously recommended evaluations based on the patient's age. In general, the recommendations emphasise the importance of routine physical assessment with accurate assessment of growth, as well as blood pressure monitoring, developmental assessment, routine vision and hearing screening, and - of paramount importance - routine cardiac evaluation.

\section{Prognosis}

Owing to the multitude of complications (both physical and psychiatric) associated with Williams 
syndrome, individuals with this condition have generally low educational and employment attainments (Howlin 2006).

\section{Wolff-Hirschorn syndrome}

\section{Background}

Patients with Wolff-Hirschorn syndrome (WHS) have a deletion of variable size involving the short arm of chromosome 4, always including the band $4 p 16$. Eighty per cent of deletions arise de novo, while $20 \%$ occur as a result of a parentally transmitted unbalanced translocation (Young 2005). The gene affected is the WHS candidate 1 gene, which has a role in the transcription process (Baradaran-Heravi 2013). The incidence is estimated at 1 in 50000 to 1 in 20000 births, with a female predilection of 2:1 (Battaglia 2008).

\section{Clinical features}

Individuals with WHS can be easily identified, as they tend to have a characteristic facial appearance, with a prominent nose due to a high forehead, prominence of the glabella, hypertelorism, epicanthal fold, and a distinct mouth with downturned corners (Battaglia 2008). This characteristic facial appearance is commonly known as the 'Greek warrior helmet' appearance. Other common clinical features include musculoskeletal and neurological abnormalities, as well as midline defects. The most commonly associated medical problems are seizures, feeding difficulties, and cardiac, ophthalmological and dental abnormalities (Battaglia 2008).

\section{Psychiatric comorbidity and intellectual disabilities}

Global developmental delay is often exhibited, with mild intellectual disability in $10 \%$, moderate in $25 \%$ and severe/profound in $65 \%$ of cases. Expressive language, although limited to guttural or disyllabic sounds in most individuals, was at the level of simple sentences in $6 \%$. Comprehension seems to be limited to a specific context. Individuals' abilities to communicate gradually improve over time as they learn more gestures to facilitate communication (Battaglia 2008).

\section{Clinical management}

Clinical management is largely symptom targeted and supportive at best. It is essential to note that patients diagnosed with WHS are prone to recurrent aspirations, and hence they are prone to recurrent episodes of respiratory infections. In view of the expected difficulties with feeding, there have been recommendations for the consideration of placement of a gastrostomy tube. In view of the presence of midline defects, routine thorough cardiovascular examination is required. In addition, in view of the presence of ptosis and hearing defects, it might also be wise to conduct audiological and ophthalmological screening periodically.

\section{Prognosis}

The prognosis of patients with WHS is considered to be favourable if the three major medical problems (seizures, feeding difficulties and developmental disabilities) are carefully investigated and managed (Battaglia 2008). If diagnosed early, cardiac, ophthalmological and dental abnormalities can be treated with good outcomes (Battaglia 2008).

\section{Cri du chat syndrome}

\section{Background}

Cri du chat syndrome (CdCS) is a genetic disorder resulting from a deletion of variable size occurring on the short arm of chromosome 5 (5p-). This rare disease has an incidence ranging from 1 in 15000 to 1 in 50000 live-born infants (Mainardi 2006). CdCS affects less than $1 \%$ of the population with mild intellectual disability; its prevalence has been previously reported as 1 in 350 among 6000 individuals with intellectual disability (Niebuhr 1978).

\section{Clinical features}

Patients with CdCS are noted to have low weight at birth (mean $2614 \mathrm{~g}$ ). In addition, they may have dysmorphic facies, characterised by microcephaly, round face, prominent large nasal bridge, hypertelorism, epicanthal folds, downward slanting palpebral fissures, downturned corners of the mouth, low-set ears, micrognathia, abnormal dermatoglyphics (transverse flexion creases) and the typical cat-like cry (Jones 2006). The phenotypic features of the cat-like cry have been localised to the region of 5p15.3 (Mainardi 2001). It is important for clinicians to note that these features might become less prominent with advancing age, which could cloud the clinical diagnosis; in particular, it appears that the face tends to become longer and narrower (Mainardi 2006). In addition, patients with CdCS may have growth retardation, sensory issues and cardiac deformities.

\section{Psychiatric comorbidity and intellectual disabilities}

Patients with this condition tend to have severe mental and developmental retardation. The IQ is usually below the 20th and 50th per centile, respectively. In a study of 26 UK children with 
CdCS, full-scale IQ on the Wechsler Intelligence Scale for Children (WISC-III) varied from below 40 (4 children) to between 40 and 57 (the remaining children), with a mean of 48 (Cornish 1999). Neuropsychological testing has revealed that patients tend to have better abilities in comprehension of speech compared with their ability to communicate (Mainardi 2006).

\section{Prognosis}

After the first year of life, survival rates are high and morbidity is low. It has been found that mortality is about $10 \%$, with $75 \%$ of premature deaths occurring in the first months of life, and up to $90 \%$ within the first year (Niehbur 1978).

\section{Rubinstein-Taybi syndrome}

\section{Background}

Rubinstein-Taybi syndrome (RSTS) generally occurs sporadically, and $55 \%$ of affected individuals show a microdeletion of chromosome 16p13.3, or a mutation in the gene encoding either CREB-binding protein or EIA-binding protein. However, these mutations cannot be found in $45 \%$ of individuals with the syndrome, leaving the diagnosis to rest on clinical features alone (Hennekam 2006). The syndrome is rare, with the birth prevalence ranging from 1 in 100000 to 1 in 125000 (Hennekam 2006).

\section{Clinical features}

RSTS is well defined by several congenital anomalies, including intellectual disability, postnatal growth deficiency, microcephaly, specific facial characteristics, broad thumbs and big toes (Rubinstein 1963). Patients with RSTS have a striking facial appearance, with highly arched eyebrows, long eyelashes, down-slanting palpebral fissures, broad nasal bridge, beaked nose with the nasal septum extending well below the alae, highly arched palate, and mild micrognathia. Their facial expression tends to have a grimace or unusual smile with almost closing of the eyes. They also often have talon cusps at the permanent incisors, and broad thumbs and broad big toes (Hennekam 2006). Common comorbidities include growth/weight problems, constipation, hypotonia, congenital heart defects, renal anomalies, problems with anaesthesia, ophthalmologic problems, orthopaedic problems, increased risk for tumours, seizures, behavioural issues and intellectual disability (Hennekam 2006).

\section{Psychiatric comorbidity and intellectual disabilities}

Affected individuals have several behavioural issues, including short attention span and poor coordination, as well as sudden mood changes in adulthood (Hennekam 2006). In addition, recent studies have highlighted the association between this disorder and characteristic behaviours such as motor stereotypies (Galera 2009). Other studies have demonstrated an age-related change in symptoms, with anxiety, mood instability and aggression being more prominent as age advances (Yagihasi 2012). However, individuals are usually described as loving, friendly and happy as children (Stevens 1990). Global intellectual disability is characteristic, with an average IQ between 35 and 50 (Hennekam 1992).

\section{Prognosis}

Survival rates in general are good, with apparently normal life expectancy and frequent reports of adults with RSTS (Hennekam 2006).

\section{Prevention of microdeletion syndromes and associated disabilities}

Prevention of microdeletion syndromes can be done via DNA-based prenatal diagnosis. The purpose of DNA-based prenatal diagnosis is usually to determine whether the fetus has inherited the disease-causing mutation(s) identified in one or both parents. It is also led by ultrasound findings that may occasionally suggest a specific disorder, such as investigations for decreased fetal motor activity in PWS (Schinzel 1986).

Karyotyping remains the gold standard of chromosome analysis; however, this technique has limited resolution and is therefore unable to reliably detect small discrete chromosomal abnormalities involving genomic regions of less than $6-10 \mathrm{Mb}$, such as microdeletions. With the advances in cytogenetics, the development of the FISH technique makes this possible. Fetal cells can be extracted from amniotic fluid samples and analysed using FISH. However, the majority of FISH assays are highly targeted and will only uncover abnormalities for which specific probes have been designed.

As such, these DNA-based prenatal diagnosis methods are mostly targeted towards families at risk of an inherited condition, and are not used as a screening test because of cost, technical complexity and limited resources. The family should first undergo molecular genetic testing and genetic counselling before embarking upon a DNA-based prenatal diagnosis (Bui 2002; Konialis 2011).

With regards to the secondary disabilities that might arise as a complication of the underlying microdeletion syndrome, other rehabilitation options may be useful, such as physiotherapy and speech and language therapies. 


\section{MCO answers}

1 a $\quad 2$ e $\quad 3 c \quad 4$ e $\quad 5 c$

\section{Conclusions}

This article has highlighted the association between common microdeletion syndromes and intellectual disabilities. Genetic testing would help in early detection, so that appropriate clinical management plans could be formulated to help individuals better manage the other complications arising from microdeletion syndromes.

\section{References}

Baradaran-Heravi A, Lange J, Asakura Y, et al (2013) Bone marrow transplantation in Schimke immune-osseous dysplasia. American Journal of Medical Genetics, 161A: 2609.

Battaglia A, Filippi T, Carey JC (2008) Update on the clinical features and natural history of Wolf-Hirschhorn (4p-) syndrome: Experience with 87 patients and recommendations for routine health supervision. American Journal of Medical Genetics Part C (Seminars in Medical Genetics), 148C: 246-51.

Boer $\mathrm{H}$, Holland A, Whittington J, et al (2002) Psychotic illness in people with Prader Willi syndrome due to chromosome 15 maternal uniparental disomy. Lancet, 359: 135-6.

Bui TH (2002) Prenatal diagnosis: molecular genetics and cytogenetics. Best Practice \& Research Clinical Obstetrics and Gynaecology, 16: 629-43

Buiting K (2010) Prader-Willi syndrome and Angelman syndrome. American Journal of Medical Genetics Part C (Seminars in Medical Genetics), 154C: 365-76

Buggenhout GV, Fryns JP (2009) Angelman syndrome. European Journal of Human Genetics; 17: 1367-73.

Clayton-Smith J (1993) Clinical research on Angelman syndrome in the United Kingdom: observations on 82 affected individuals. American Journal of Medical Genetics, 46: 12-5.

Committee on Genetics (2001) Health care supervision for children with Williams syndrome. Pediatrics, 107: 1192

Cornish K, Bramble D, Munir F et al (1999) Cognitive functioning in children with typical cri du chat (5p-) syndrome. Developmental Medicine and Child Neurology, 41: 263-6

Dykens EM, Hodapp RM, Walsh K, et al (1992) Profiles, correlates, and trajectories of intelligence in Prader-Willi syndrome. Journal of the American Academy of Child and Adolescent Psychiatry, 31: 1125-30.

Galera C, Taupiac E, Fraisse S, et al (2009) Socio-behavioral characteristics of children with Rubinstein-Taybi syndrome. Journal of Autism and Developmental Disorders, 39: 1252-60.

Golding-Kushner KJ, Weller G, Shprintzen RJ (1985) Velo-cardio-facial syndrome: language and psychological profiles. Journal of Craniofacial Genetics and Developmental Biology, 5: 259-66.

Goldmuntz E, Clark BJ, Mitchell LE, et al (1998) Frequency of 22q11 deletions in patients with conotruncal defects. Journal of the American College of Cardiology, 32: 492-8.

Gothelf D, Frisch A, Michaelovsky E, et al (2009) Velo-cardio-facial syndrome. Journal of Mental Health Research in Intellectual Disabilities, 2: 149 .

Hennekam RC, Baselier JC, Beyaert E, et al (1992) Psychological and speech studies in Rubinstein-Taybi syndrome. American Journal of Mental Retardation, 96: 645-60.

Hennekam RC (2006) Rubinstein-Taybi syndrome. European Journal of Human Genetics, 14: 981-85.

Howlin P, Udwin 0 (2006) Outcome in adult life for people with Williams syndrome - results from a survey of 239 families. Journal of Intellectual Disability Research, 50: 151-60.

Jin DK (2011) Systematic review of the clinical and genetic aspects of Prader-Willi syndrome. Korean Journal of Pediatrics, 54: 55-63.
Jones KL (2006) Smith's Recognizable Patterns of Human Malformation (6th edn). Elsevier Saunders, 2006.

Konialis C, Hagnefelt B, Sevastidou S, et al (2011) Uncovering recurrent microdeletion syndromes and subtelomeric deletions/duplications through non-selective application of a MLPA-based extended prenatal panel in routine prenatal diagnosis. Prenatal Diagnosis, 31: 571-7.

Laan LA, van Haeringen A, Brouwer OF (1999) Angelman syndrome: a review of clinical and genetic aspects. Clinical Neurology and Neurosurgery, 101: 161-70.

Larson AM, Shinnick JE, Shaaya EA, et al (2015) Angelman syndrome in adulthood. American Journal of Medical Genetics A, 167A: 331-44.

Mainardi PC, Perfumo C, Calì A, et al (2001) Clinical and molecular characterisation of 80 patients with $5 p$ deletion: genotype-phenotype correlation. Journal of Medical Genetics, 38: 151-8.

Mainardi PC (2006) Cri du chat syndrome. Orphanet Journal of Rare Diseases, 1: 33

Martens MA, Wilson SJ, Reutens DC (2008) Williams syndrome: a critical review of the cognitive, behavioural, and neuroanatomical phenotype. Journal of Child Psychology and Psychiatry, 49: 576-608.

Martin A, State M, Koenig K, et al (1998) Prader-Willi syndrome. American Journal of Psychiatry, 155: 1265.

Morris CA, Mervis CB (1999) Williams syndrome. In Handbook of Neurodevelopmental and Genetic Disorders in Children (eds S Goldstein, CR Reynolds): 555-90. Guilford Press.

Morris CA, Mervis CB (2000) Williams syndrome and related disorders. Annual Review of Genomics and Human Genetics, 1: 461-84.

Niarchou M, Martin J, Thapar A, et al (2015) The clinical presentation of-hyperactivity disorder (ADHD) in children with 22q11.2 deletion syndrome. American Journal of Medical Genetics B Neuropsychiatric Genetics, 168: 730-8.

Niebuhr E (1978) The cri du chat syndrome. Epidemiology, cytogenetics and clinical features. Human Genetics, 44: 227-75.

Nixon GM, Brouillette RT (2002) Sleep and breathing in Prader-Willi syndrome. Pediatric Pulmonology, 34: 209-17.

Ornoy A, Weinstein-Fudim L, Ergaz Z (2016) Genetic syndromes, maternal diseases and antenatal factors associated with autism spectrum disorders (ASD). Frontiers in Neuroscience, 10: 316

Radoeva PD, Fremont W, Antshel KM, et al (2017) Longitudinal study of premorbid adjustment in 22q11.2 deletion (velocardiofacial) syndrome and association with psychosis. Development and Psychopathology, 29: 93-106

Rubinstein JH, Taybi H (1963) Broad thumbs and toes and facial abnormalities. American Journal of Diseases of Children, 105: 588-608.

Ryan AK, Goodship JA, Wilson DI, et al (1997) Spectrum of clinical features associated with interstitial chromosome 22q11 deletions: a European collaborative study. Journal of Medical Genetics, 34: 798-804.

Schinzel A (1986) Approaches to the prenatal diagnosis of the PraderWilli syndrome. Human Genetics, 75: 327

Schinzel A (1988) Microdeletion syndromes, balanced translocations, and gene mapping. Journal of Medical Genetics, 25: 454-62.

Shprintzen RJ, Siegel-Sadewitz VL, Amato J, et al (1985) Anomalies associated with cleft lip, cleft palate, or both. American Journal of Medical Genetics, 20: 585-95.

Shprintzen RJ (2008) Velo-cardio-facial syndrome: 30 years of study. Developmental Disabilities Research Reviews, 14: 3-10.

Simon TJ, Bish JP, Bearden CE, et al (2005) A multilevel analysis of cognitive dysfunction and psychopathology associated with chromosome 22q11.2 deletion syndrome in children. Development and Psychopathology, 17: 753-84.

Stevens CA, Hennekam RC, Blackburn BL (1990) Growth in the Rubinstein-Taybi syndrome. American Journal of Medical Genetics Supplement, 6: 51-5.

Sullivan KE (2008) Chromosome 22q11.2 deletion syndrome: DiGeorge syndrome/velocardiofacial syndrome. Immunology and Allergy Clinics of North America, 28: 353-66. 
Swillen A, Devriendt K, Legius E, et al (1997) Intelligence and psychosocial adjustment in velocardiofacial syndrome: a study of 37 children and adolescents with VCFS. Journal of Medical Genetics, 34: 453-8.

Tang KL, Antshel KM, Fremont WP, et al (2015) Behavioral and psychiatric phenotypes in 22q11.2 deletion syndrome. Journal of Developmental and Behavioral Pediatrics, 36: 639-50.

Tordjman S, Anderson GM, Botbol M, et al (2012) Autistic disorder in patients with Williams-Beuren syndrome: a reconsideration of the Williams-Beuren syndrome phenotype. PLoS ONE, 7: e30778.

Verhoeven WM, Tuinier S, Curfs LM (2003) Prader-Willi syndrome: the psychopathological phenotype in uniparental disomy. Journal of Medical Genetics, 40: e112.
Williams CA (2005) Neurological aspects of the Angelman syndrome. Brain Development, 27: 88-94.

Williams CA, Beaudet AL, Clayton-Smith J, et al (2006) Angelman syndrome 2005: updated consensus for diagnostic criteria. American Journal of Medical Genetics A, 140: 413-8.

Williams CA, Driscoll DJ, Dagli Al (2010) Clinical and genetic aspects of Angelman syndrome. Genetics in Medicine, 12: 385-95.

Yagihasi T, Kosaki K, Okamoto N, et al (2012) Age-dependent change in behavioral feature in Rubinstein-Taybi syndrome. Congenital Anomalies, 52: 82-6.

Young ID (2005) Medical Genetics: 63-66, 84-86. Oxford University Press.

\section{MCQs}

Select the single best option for each question stem

1 The estimated incidence of intellectual disability owing to microdeletion syndromes in high- and middle-income countries is:

\section{a $1-3 \%$}

b $4-5 \%$

c $5-7 \%$

d $7-10 \%$

e More than $10 \%$.

2 Schizophrenia occurs most frequently in:

a Prader-Willi syndrome

b Angelman syndrome

c Williams syndrome

d cri du chat syndrome

e 22q11.2 deletion syndrome.
310 of $50-60$, with higher verbal than performance intelligence score, is commonly found in:

a Prader-Willi syndrome

b Angelman syndrome

c Williams syndrome

d cri du chat syndrome

e 22q11.2 deletion syndrome.

4 The second most common cause of developmental delay and the major cause of congenital heart disease after Down syndrome is:

a Prader-Willi syndrome

b Angelman syndrome

c Williams syndrome

d cri du chat syndrome

e 22q11.2 deletion syndrome.
5 Common comorbidities for individuals with 22q11.2 deletion syndrome do not include:

a hyperkinetic disorder

b oppositional defiant disorder

c enuresis

d separation anxiety disorder

e obsessive-compulsive disorder. 